\title{
РЕАЛІЗАЦІЇ ПРОЕКТІВ ВІРТУАЛЬНОЇ РЕАЛЬНОСТІ ЯК РІЗНОВИДУ ВАРІАТИВНОГО ЕКРАННОГО ТВОРУ
}

Стаття присвячена огляду сучасних видовищних проектів віртуальної реальності з точки зору використання ними творчих та технічних досягнень кінематографа. Подано огляд тих засобів, щэо їх проекти віртуальної реальності запозичували у кіно. В статті розглянуто атракціони віртуальної реальності «Зоряні війни. Секрети імперї̈» та «Мисливці за привидами: Вимір», а також проекти серіального типу «Зникла», «Галькіон». Визначається їх відмінність від подібних кіно- та телепроектів. Розглянуто принципи застосування варіативності в кожному з ичих проектів, а також згадано про проекти прямих трансляцій для систем віртуальної реальності. Подано огляд перспектив розвитку подібних творів.

Ключові слова: віртуальна реальність, варіативність, стереокіно, $3 D$.

Статья посвящена обзору современных зрелищных проектов виртуальной реальности с точки зрения использования ними творческих и технических достижений кинематографа. Дан обзор тех средств, которые проекты виртуальной реальности заимствовали у кино. В статье рассмотрень аттракционы виртуальной реальности «Звездные войны. Секреты империи» и «Охотники за привидениями: Измерение», а также проекты сериального типа «Исчезнувщая», «Галькион». Определяется их отличие от подобных кино- и телепроектов. Рассмотрены принципы применения вариативности в каждом из этих проектов. Упоминается о проектах прямых трансляций для систем виртуальной реальности. Подан обзор перспектив развития подобных произведений.

Ключевые слова: виртуальная реальность, вариативность, стереокино, $3 D$.

The article is devoted to the review of modern spectacular projects of virtual reality in terms of their use of creative and technical achievements of cinema. An overview of the instrumentality that projects of virtual reality borrowed from the cinema is given. The article deals with attractions of virtual reality «Star Wars. Secrets of the Empire» and "Ghostbusters: Dimension», as well as projects of serial type "Gone», "Halcyon». Their difference from similar films and TV projects is determined. The principles of variability in each of these projects are considered. Article also tells about live streaming projects for virtual reality systems. An overview of the prospects for the development of such works is given.

Key words: virtual reality, variability, stereocinema, $3 D$.

У світі активно розвиваються технології віртуальної реальності. $€$ певні розробки, такі як Oculus Rift, SteamSight, Project Morpheus, які вже мають комерційне застосування, та багато інших, котір проходять стадії випробувань. Тривалий час основним застосуванням цих розробок були наукові та ігрові проекти, проте останніми кроками їх дедалі частіше використовують у кіно та на телебаченні. При цьому функціонально вони, як правило, пов'язані з інтерактивним проектами. Таке поєднання робить цей вид контенту різновидом варіативного екранного твору. В українських реаліях реалізація подібних проектів поки що не заохочує великих інвестицій, тому вітчизняні митці мають мало власного досвіду в цій галузі. Водночас український глядач має доступ до світового контенту, який можуть запропонувати проекти віртуальної реальності. Щоб не повторювати помилок піонерів цього напряму, треба провести огляд зарубіжних проектів цього типу і визначити ключові фактори їх успіху.

Темі віртуальної реальності присвячено безліч літератури технічного, філософського, культурологічного та інших напрямів. Автори полемі- 
зують на тему як самого значення терміна «віртуальна реальність», так і впливу різноманітних розробок на всі сфери людського життя. Це твори П. Леві, Г. Рейнгольда, А. Крокера, М. Кастельса, У. Еко, Е. Тоффлера та інших. Проте треба зазначити, що за останні 80 років поняття віртуальної реальності змінювалось зі зміною технологій, і у статті йдеться про «віртуальну реальність», яка створюється конкретними сучасними технічними розробками, що часто надто відрізняється від уявлення про неї в творах вищезазначених авторів. Зокрема твір «Театр та його двійник» Антонена Арто, де вперше введено поняття «віртуальна реальність», хоча і дає уявляння про суть цього поняття та його потенціал у візуальній культурі, не міг в еру, коли не було комп'ютерів у сучасному розумінні цього слова, аналізувати сучасні тенденції цього напряму. Серед сучасних авторів дотичними є праці дослідників інтерактивної драматургії, зокрема Девіда 3. Зальца, Улли Йоргансен, Куанху Фен. Проте ці автори змістили фокус своїх досліджень у бік театру та інсталяцій, тоді як кіно та телевізійне застосування переважно залишились поза їх увагою.

Стаття ставить за мету дослідити поєднання інтерактивних технологій та віртуальної реальності з точки зору створення екранних творів з варіативним сюжетом.

Сучасні розробки у сфері віртуальної реальності значною мірою базуються на технічних та творчих досягненнях кіно. Першим з них є стереозображення, яке зараз називається 3D. У першій половині XIX століття був винайдений стереоскоп. Він отримав чимале поширення у всьому світі після Великої виставки досягнень промисловості усіх націй, яка відбулася у 1851 році. На початку наступного століття стерео прийшло у кіно. Прем'єра спеціально знятої у стерео стрічки «Сила любові» відбулася у 1922 році. У 1933 році Луї Люм’єр перезняв у стерео стрічку 1895 року «Прибуття потягу». В цей час користувалися різними системами для зйомки та демонстрації стереофільмів. Було багато фільмів, і назва одного 3 них «Майже доторкнувшись» («Zum Greifen nah») добре характеризує основну суть тогочасних стереокартин. Сергій Ейзенштейн стверджував, що неможливо сумніватися у переможному майбутньому стереокіно [1, 435]. 1952-1954 роки були золотою ерою стереокіно. Кіностудії створювали об'ємні стрічки, не в останню чергу щоб виграти конкуренцію 3 телевізором, який надавав усі інші функції, на яке здатне кіно, окрім цієї. Стереоефект використовувався прямолінійно, ви можете побачити те саме, але значно реальніше. Хоча сьогодні об'єм у фільмах створюється значно майстерніше, проте основна функція 3D в більшості фільмів - це реалізм. Саме це було потрібно сучасним проектам віртуальної реальності. В попередні роки були проекти, які обходилися без стереозображення, проте для успішного виходу проектів на масовий ринок потрібне було 3D.

Наступний елемент, який віртуальна реальність позичила у кіно, це сценарій та, відповідно, драматургія. Адже технологічні проекти віртуальної реальності - це лише засіб, для повноцінного функціювання їм потрібен контент. I тут розробники віртуальної реальності йшли двома шляхами, це використання творчого арсеналу комп'ютерних ігор і використання творчого потенціалу кінематографа. Причому вибір на користь кіно стосується саме останніх розробок.

Зараз Lucasfilm, ILMxLAB, та The VOID готують новий атракціон, побудований на віртуальній реальності: «Зоряні війни. Секрети імперії». Хоча атракціон відкриється лише 16 грудня 2018 року, проте оприлюднено вже достатньо деталей, щоб зробити певні висновки про його побудову. Учасниками мають стати четверо людей, які за допомогою шолому віртуальної реальності, наплічника з обладнанням та лазерної зброї у спеціально обладнаному приміщенні перетворяться на команду повстанців, відправлену на планету Мутафар, аби віднайти важливі для повстанців розвіддані. Їх віртуальним гідом буде робот К-2SO 3 фільму «Бунтар Один. Зоряні Війни. Історія» [2].

Отже ми маємо не просто теоретичне поєднання кіно та віртуальної реальності, а атракціон, що $є$ фактично частиною історій всесвіту «Зоряних війн». За трейлером можна судити про елементи сюжету атракціону. В нього входять переміщення по планеті з метою пошуку чогось, зіткнення 3 ворожими силами із застосуванням лазерної зброї, спілкування з віртуальними персонажами. Тут можна побачити необхідні основні елементи кіносценарію: є команда протагоністів, вони мають певну мету, на шляху до цієї мети їм треба буде долати певні перепони. Важко судити, як побудовані перипетії, але виходячи з багатого досвіду Lucasfilm у роботі над фільмами всесвіту «Зоряних війн» можна сподіватися, що на шляху до мети герої переживуть свої успіхи та розчарування, можливо, навіть момент катарсису.

Виходячи $з$ цього, можна сказати що побудова сюжету атракціону відповідає схемі побудови кінострічок з варіативним сюжетами. Те, що складно втілити, працюючи для стандартного кіноекра- 
на, стає можливим і навіть необхідним при застосуванні віртуальної реальності [3, 143]. Проте, якщо у фільмі «Розгадка» («Clue») 1985 року була лише одна точка варіативності з трьома кінцівками, які демонструвалися одна за одною, а рімейк цього сюжету у серіалі «Псих» («Рsych»), серія «100 розгадок» («100 Clues»), демонструвався 3 різними кінцівками для двох узбереж Сполучених Штатів Америки, то в «Секретах імперії спільним може бути лише початок, тоді як подальший хід сюжету може сильно змінюватись залежно від дій героїв. Можна уявити, що фінал атракціону має не менше двох варіантів, успішний та неуспішний. Або групу відповідних варіантів, якщо, наприклад, герої доберуться до фіналу не в повному складі. При цьому критикам варіативного кіно, які стверджують, що варіативність убиває творчість, впускаючи глядача до розвитку сюжету, атракціон «Секрети імперії» протиставляє напрямок руху історії, замість звичного для кіноглядача лінійного сюжету. Адже між спільним початком та кінцівкою (чи групою кінцівок) має бути певна лінія, яка визначиться поведінкою героїв. Нехай ця лінія може бути різної форми (якщо уявити точки варіативності сюжету у вигляді графа), проте іiі напрямок завжди той самий, від початку і до кінця. Отже всі точки варіативності і, відповідно, всі лінії мають бути заздалегідь прораховані авторами, на яких очікує значно складніше завдання, ніж на митців лінійного кіно, проте це надає інші, ширші можливості для творчості. В проекті такого масштабу мають бути десятки, якщо не сотні точок варіативності, з відповідною формою графу типу «дерево».

Окрема специфіка подібного проекту порівняно 3 наявними кінофільмами 3 варіативним сюжетом полягає у діленні точок варіативності на класи. Ця специфіка виникає через особливості технічної побудови проектів віртуальної реальності. Якщо ми беремо кінофільм 3 варіативним сюжетом, то абсолютно всі сюжетні ліній мають бути відзнятими заздалегідь. Це призводить до того, що 3'являється сенс робити варіативність лише значного ступеня. Наприклад, у фільмі «Розплата» 1999 року у театральній версії головним негативним персонажем виступає Бронсон у виконанні Кріса Крістоферсена, тоді як у режисерській версії 2006 року це Саллі Келерман. Так само кульмінаційна сцена у версії 2006 року відбувається у метро, тоді як у версії 1999 року в занедбаному приміщенні. Робити варіативність із того, чи влучив герой в опонента 3 першого пострілу чи з другого, економічно не виправдано, i не несе нічого додаткового для глядача порівняно 3 фільмом $з$ лінійним сюжетом.

У «Зоряних війнах. Секрети імперії» зображення, що його бачить глядач (учасник), генерується потужним комп'ютером, який, залежно від поведінки учасників може згенерувати сотні варіантів однієї і тієї ж сцени. Тому постає потреба у поділі точок варіативності на класи. Припустимо, герої потрапляють у певне приміщення, де, як показано у трейлері, їх атакують штурмовики імперії. Отже вхід до цього приміщення та вихід 3 нього - це основні точки варіативності, адже якщо герої не увійдуть, то їх не атакують, якщо вони не переможуть, то атракціон піде іншим сюжетним шляхом, ніж в разі їх перемоги. Але є й другорядні точки, наприклад, хто із героїв уразив кого із ворогів, де перебував герой, коли робив постріл і т. д. Якщо герої перемогли у цій сцені, то для сюжету неважливо, як вони це зробили, проте варіантів цієї перемоги можуть бути сотні і тисячі, і це, якщо дивитись на хід усього атракціону, також є варіативністю.

Іншим цікавим прикладом поєднання кіно та віртуальної реальності $\epsilon$ проект «Зникла» («Gone») 2016 року. На відміну від стрічки «Зоряні війни. Секрети імперії», цей проект, або, як його автори називають, шоу, є повністю відзнятим за допомогою камер, що знімають на 360 градусів. Інтерактивність тут має значно меншу свободу, ніж у попередньому прикладі. Глядач може лише обирати точку, з якої він дивиться сцену, та напрямок погляду [4].

Сюжет цього шоу розгортається навколо мами дев' ятирічної дівчини, яка шукає свою зниклу дочку. Дочка зникає посеред дня, у присутності десятка свідків. Мамі доводиться проводити розслідування, шукаючи розгадки, спілкуючись зі свідками. Шоу розбито на 11 епізодів. Сцени йдуть по 5-6 хвилин, і шоу відбувається в реальному часі, тобто в рамках сцен немає звичного нам кіномонтажу.

Глядач не $є$ безпосереднім учасником шоу, він не асоціюється 3 жодним персонажем. Завдання глядача - бути уважним. За допомогою шолому віртуальної реальності він може оглядати увесь простір знімального майданчика. Він не залучений до сюжету i не може змінити його хід, але він може оглядати сцену у пошуках «міток», які дають йому можливість перейти на іншу точку огляду, слухати розмови і робити власні висновки щодо проведення розслідування. 3 розвитком сюжету ці мітки зникають, тому для авторів важливо, щоб глядачі переглядали кожен епізод ба- 
гаторазово, повертаючись до сцен, щоб оглянути ïx $з$ іншої перспективи. Таким чином, формально в цьому шоу немає варіативності, адже сюжет не змінюється незалежно від того, хоч скільки разів переглядається, і дії глядача не можуть вплинути на сюжет. Проте кожен перегляд для глядача відрізнятиметься від попереднього, адже навіть при перегляді з тієї самої точки глядач крутитиме головою в шоломі віртуальної реальності по-різному, отже для нього шоу буде іншим, відповідно варіативним. Ця варіативність подібна до того, що відчував глядач при перегляді фільму «Расьомон», проте зроблена на іншому технічному рівні.

У шоу такого типу немає точок варіативності у загальному розумінні. Адже варіативність історії зміщується до варіативності перегляду. Це все одно варіативність сюжету, бо побачене та почуте дає змогу по-різному трактувати історію, і глядач при кожному перегляді шоу бачить різне.

Також важливо зазначити, що для «Зоряних війн. Секрети імперії» потрібне спеціальне обладнання, тобто шолом та рюкзак з апаратурою, а також спеціально підготоване приміщення, де рухатимуться герої. Тоді як для «Зниклої» потрібен лише шолом віртуальної реальності, причому не конкретна модель, а одна 3 багатьох. Таким чином, аудиторія «Зниклої» може бути набагато численнішою за аудиторію «Зоряних війн...». (Наразі такі атракціони планується відкрити лише у двох точках Сполучених Штатів.)

Ще один приклад атракціону з віртуальною реальністю показує, наскільки близькими стають такі атракціони до комп'ютерних ігор, не пориваючи, проте, свої зв'язки з кінематографом. До створення «Зоряних війн. Секрети імперії» компанія The VOID разом із Sony Pictures розробила атракціон «Мисливці за привидами: Вимір», відкритий у 2016 році. Цей атракціон прив'язаний до нової версії відповідного фільму. Учасники атракціону можуть пройтися штаб-квартирою мисливців за привидами, поспілкуватися з персонажами, а потім взяти участь у полюванні за привидом [5]. Таким чином, як і в «Зоряних війнах...» $є$ сюжетний зв'язок із фільмом, $є$ певний сюжет, проте порівняно $з$ кіно все надто спрощено. Немає складної сюжетної лінії, немає перипетій, після нескладного вступу починається полювання. Таким чином, цей атракціон стоїть на межі між екранним твором та комп’ютерною грою. На відміну від «Зоряних війн» точки варіативності немає сенсу ділити на категорії, жодна 3 них не змінює ходу сюжету, вони всі є другорядними, бо змінюють лише дрібниці на шляху героїв від початку до кінця історії.
Іншим цікавим застосуванням віртуальної реальності $є$ проект «Галькіон» («Halcyon»). Це суміш типового телевізійного серіалу та проекту віртуальної реальності. Він складається 3 15-ти серій. Десять із них - це звичайні короткометражки, а ще п'ять - інтерактивні проекти віртуальної реальності. Сюжет проекту побудований навколо впровадження віртуальної реальності в життя людства. Існує корпорація, яка вживляє людям елементи, що підключають їх до системи доповненої реальності, у них з'являється віртуальний асистент, який допомагає їм у їхніх справах. $€$ також рух опору, який виступає за «чисте людство». На початку першої серії відбувається таємниче вбивство голови ради директорів корпорації, i детектив Джулія Довер та ії віртуальний партнер Аша беруться до розслідування [6].

Загальний сюжет твору залишається незмінним, відзняті десять серій не мають жодних варіантів, проте серії, призначені для віртуальної реальності, керуються глядачем, який може пересуватися місцем злочину, збирати докази, шукати сліди злочинця та іншими методами допомагати розкрити злочин.

Серії, призначені для віртуальної реальності, розташовуються на часовій вісі між звичайними серіями і мають відповідну нумерацію: $1.5,2.5$, 4,5 і т.д. Сама побудова проекту не викликає сумнівів, що перед нами екранний твір із типовою серіальною драматургією. Точками варіативності тут виступають кінці та початки серій для віртуальної реальності. Таким чином, якщо побудувати сюжетну лінію як графу, ми побачимо прямі лінії на місці звичайних серій, і великі розгалуження на місці віртуальних. Звісно, віртуальні серії не $\epsilon$ зразком «відкритого світу» і робити в них глядач може лише те, що передбачено авторами проекту. В цих серіях немає активної дії, і вони не передбачають суттєвих перипетій на шляху розвитку сюжету. Ці серії радше допомагають глибше зрозуміти сюжет проекту, заглибитись в атмосферу 2040 року та часу, коли людство живе в умовах віртуальної реальності.

Подібна побудова проекту нагадує підхід, коли телевізійний серіал знімається 3 розрахунком на випуск не лише багатосерійної версії, а й повнометражного проекту. В такому разі варіативність зазвичай впливає, насамперед, на деталізацію сюжету, не змінюючи його розвитку. Застосування цього приму з використанням віртуальної реальності дає той самий ефект, посилений реалізмом, ефектом присутності та можливістю стати учасником екранної дії. 
Проект (його віртуальна частина) надається для перегляду з використанням Oculus Rift та Gear $\mathrm{VR}$, що робить його доступним для доволі широкої аудиторії.

Окремою формою екранних творів із застосуванням віртуальної реальності є прямі трансляції подій, які знімаються на камери з кутом огляду 360 градусів. На початку це були лише окремі трансляції переважно через Інтернет, зараз група Fox розпочала телевізійні трансляції спортивних подій [7]. Ці трансляції йдуть в реальному часі, але глядач може за допомогою шолому віртуальної реальності роздивлятися довкола так, ніби він присутній на відповідній події. Деякі ентузіасти за цим принципом намагаються робити розмовні, комедійні або пізнавальні шоу, проте поки що такий напрям не користується великою популярністю. Можна пояснити це тим, що відмінність таких малобюджетних проектів від звичайних трансляцій за допомогою стандартної відеокамери для глядача $\epsilon$ незначною. Створити цікаве зображення поза межами основної сфери зору ведучого такої програми вкрай складно, отже не має особливого сенсу дивитися його із застосуванням віртуальної реальності.

Створення цікавих видовищних проектів із застосуванням віртуальної реальності потребує великих коштів i, відповідно, великої аудиторії для комерційного успіху. Такі проекти як «Зоряні війни. Секрети імперії» та «Мисливці за привидами: Вимір», потребують спеціально підготованого приміщення, отже глядач (учасник) має прибути до цього приміщення. Обидва атракціони мають по дві локації на цілий світ, i, хоча ці локації розташовані у місцях з великим потоком людей (парках розваг), їх аудиторія обмежена самою пропускною здатністю атракціону. Такі проекти як «Зникла» та «Галькіон», доступні для перегляду в домашніх умовах, що робить їх потенційну аудиторію значно ширшою. Щоправда, платою за це є обмеження у русі, адже домашні глядачі не можуть міняти позицію в реальному світі так, щоб це відображалося у віртуальному. Тому в перших двох проектах участь глядача $є$ активною, він стає одним 3 протагоністів сюжету, тоді як в останніх двох - він другорядний персонаж, втрата якого не $\epsilon$ важливою для сюжету. Проект «Галькіон» міг би бути більш цікавим, якби від дій глядача у віртуальних серіях змінювалася сюжетна лінія у звичайних частинах, проте це неодмінно потребувало б значно більших витрат від авторів проекту.

Сьогодні ситуація із впровадженням проектів віртуальної реальності швидко змінюється на краще. З'являються нові шоломи, можливо, не такі якісні як флагмани індустрії, проте значно доступніші за ціною. Це кардинально збільшує потенційну аудиторію таких проектів. Можливість використовувати мобільні телефони для перегляду проектів віртуальної реальності в рамках Cardboard робить цю розвагу ще доступнішою. Поширенню цих пристроїв слугує те, що за їх допомогою можна переглядати також звичайні 3D фільми, які вже стали достатньо масовими. Вперше з часів появи 3D глядач може насолоджуватись картинами, створеними в часи всіх хвиль популярності стереозображень. Відмінність між різними форматами стереокіно раніше не давала можливості без коштовних операцій переглянути стрічки, створені раніше. Сьогодні завдяки приладам віртуальної реальності все, що переведене у електронний формат $є$ доступним для перегляду у домашніх умовах без використання дорогих 3D-телевізорів. Багато глядачів у своєму сприйнятті розглядають проекти віртуальної реальності (які не $\epsilon$ іграми), як 3D фільми з функцією інтерактиву, отже $\epsilon$ потенційною аудиторією, яка готова сприймати ці проекти саме як екранні твори нового покоління.

Отже сучасний контент для систем віртуальної реальності значною мірою запозичив творчі та технічні досягнення мистецтва кіно, зі свого боку, збагативши їх можливістю інтерактивності. Варіативність сюжетів, яка наявна у кіно не одне десятиріччя, але яку важко використовувати в рамках сучасного кіно та телебачення, отримує завдяки віртуальній реальності потужну технічну базу. Точки варіативності, кількість яких та ступінь впливу на сюжет були відповідно мінімальні та максимальні, в умовах проектів віртуальної реальності втрачають свої обмеження. Максимум свободи у використанні варіативності надають проекти, в яких зображення не є відзнятим заздалегідь, а створюється в реальному часі комп'ютером. Класичні принципи побудови сценарію залишаються актуальними $\mathrm{i}$ для проектів віртуальної реальності. Окремим напрямом є екранні твори традиційного характеру, але відзняті з використанням камер із кутом огляду 360 градусів. Кількість та доступність систем віртуальної реальності швидко зростає, що зумовить збільшення попиту на відповідний контент.

Надалі цікаво було б дослідити розмиття кордонів і взаємовплив між проектами для віртуальної реальності, які тяжіють до екранних творів, та іграми для віртуальної реальності. Також цікаво розглянути елементи драматургії проектів доповненої реальності та театру з ефектом присутності. 


\section{Джерела та література}

1. Эйзенштейн С. М. О стереокино / Сергей Михайлович Эйзенштейн. Избранные произведения ; собр. соч. в 6 т. М. : Исскуство, 1964. - Т. 3. - 672 с.

2. ILMxLAB and The VOID's Star Wars: Secrets of the Empire Trailer and Details Revealed [Електронний ресурс] // starwars.com. - 2017. - Режим доступу: http://www. starwars.com/news/ilmxlab-the-void-star-wars-secrets-ofthe-empire-trailer-and-details-revealed.

3. Липков А. И. Проблемы художественного воздействия: принцип аттракциона / А. И. Липков. - М. : Наука, 1990. $240 \mathrm{c}$.

4. Lee N. 'Gone' is a VR thriller from 'Walking Dead' team and Samsung [Електронний ресурс] / Nicole Lee // engadget. com. - 2015. - Режим доступу: https://www.engadget. com/2015/12/04/gone-vr-thriller/.

5. Giardina C. 'Ghostbusters' Virtual Reality Experience to Open at Madame Tussauds New York [Електронний pecypc] / Carolyn Giardina // The hollywood reporter. - 2016. Режим доступу: http://www.hollywoodreporter.com/behindscreen/ghostbusters-virtual-reality-experience-open-892071.

6. Halcyon [Електронний ресурс] - Режим доступу: http:// halcyonvr.com/\#page-2.

7. Roettgers J. Fox Sports Streams College Football Match in Virtual Reality [Електронний ресурс] / Janko Roettgers //
Variety. - 2016. - Режим доступу: http://variety.com/2016/ digital/news/fox-sports-college-football-vr-1201858653/.

\section{References}

1. Eisenstein, S. M. (1964). About stereo cinema. Selected Works Collected Works in 6 volumes. (Vols. 3). - M. : Isskustvo [in Russian].

2. ILMxLAB and The VOID's Star Wars: Secrets of the Empire Trailer and Details Revealed (2017). - URL: http://www. starwars.com/news/ilmxlab-the-void-star-wars-secrets-ofthe-empire-trailer-and-details-revealed

3. Lipkov, A. (1990). Problems of artistic influence: the principle of attraction. - M. : Nauka [in Russian].

4. Lee, N. (2015). 'Gone' is a VR thriller from 'Walking Dead' team and Samsung. - DOI: https://www.engadget. com/2015/12/04/gone-vr-thriller/

5. Giardina, C. (2016). 'Ghostbusters' Virtual Reality Experience to Open at Madame Tussauds New York. - URL: http://www. hollywoodreporter.com/behind-screen/ghostbusters-virtualreality-experience-open-892071

6. Halcyon. (2016). - URL: http://halcyonvr.com/\#page-2

7. Roettgers, J. (2016) Fox Sports Streams College Football Match in Virtual Reality. - URL: http://variety.com/2016/ digital/news/fox-sports-college-football-vr-1201858653/ 